\title{
Regulating flavours in cigarettes: A call to action
}

\section{Christina N. Kyriakos ${ }^{1}$}

Flavoured cigarettes threaten tobacco control efforts by masking the harshness of tobacco smoke, reducing perceptions of harmfulness, and facilitating smoking initiation ${ }^{1}$. Menthol, the most prominent cigarette flavour, has unique sensory properties that can promote addiction through reinforcing the actions of nicotine on the brain ${ }^{1}$. In addition to menthol's effect on sensory perceptions, recent studies indicate that the cigarette package design of these products may also facilitate use. In particular, innovative crushable filter capsules may enhance the ritual behaviour of cigarette smoking ${ }^{2}$. Differences between menthol and nonmentholated cigarette packaging and labelling have also been observed ${ }^{3}$.

Flavoured cigarettes are further used disproportionately by vulnerable populations, including adolescents and young adults, racial/ethnic and sexual minority groups ${ }^{4-6}$. Studies have found that compared to non-flavoured cigarette users, menthol and other flavoured cigarette users are less nicotine dependent, which is a predictor of quit attempts ${ }^{7}$. This is promising in light of tobacco control policies regulating flavours, including menthol, such as the European Tobacco Products Directive (TPD), which went into effect in May 2016 requiring European Union (EU) Member States to ban characterising flavours in cigarettes with a grace period until May 2020 for menthol ${ }^{8}$. Such policies, which have gained momentum in other countries worldwide ${ }^{1,9}$, have created an unprecedented opportunity not to just prevent smoking initiation but to facilitate smokers of flavoured cigarettes to quit.

Unfortunately, the maximum impact of policies regulating flavours may not be attained without simultaneous efforts to promote smoking cessationnamely implementation of Article 14 of the World Health Organization Framework Convention on Tobacco Control (WHO FCTC). In a study of adult smokers in the EU, only a minority of menthol cigarette users responded that they would quit smoking when the TPD ban on menthol came into effect ${ }^{5}$. As the menthol ban in the EU takes effect in May of this year, now more than ever we must prioritize efforts to promote smoking cessation and reduce barriers faced in implementing WHO FCTC Article $14^{10}$. In light of the scarcity of research in flavour regulations, coupled with a lack of full guidelines of WHO FCTC Article 9 (Regulation of the contents of tobacco products) ${ }^{11}$, it is further critical to identify the best practices for regulating flavours and evaluating their impact to inform future policies in other countries. Tobacco control advocates, researchers and policymakers should be encouraged to initiate or continue the regulation of flavours in cigarettes, evaluate its impact and maximise its implementation through supporting smokers to quit.

\section{REFERENCES}

1. World Health Organization. Case Studies for Regulatory Approaches to Tobacco Products: Menthol in Tobacco Products. Geneva, Switzerland: World Health Organization; 2018. https://apps.who.int/iris/bitstream/handle/10665/260417/WHO-NMH-PND-18.1-eng.
AFFILIATION

1 School of Medicine, University of Crete, Heraklion, Greece

CORRESPONDENCE TO

Christina N. Kyriakos. School of Medicine, University of Crete, Heraklion, 715 00, Greece. E-mail: ckyriakos@tobcontrol.eu ORCID ID: https://orcid.org/0000-00030486-9152

\section{KEYWORDS}

flavours, menthol, WHO FCTC, tobacco control policies, Tobacco Products Directive, smoking cessation

Received: 13 May 2020 Accepted: 14 May 2020 
pdf;jsessionid=05F225BB6478EA5F32C804CDA2C537C2?sequence=1. Accessed May 13, 2020.

2. Schneller L, Mahoney M, Bansal-Travers M, McCann S, O'Connor R. Impact of menthol delivery methods on smoker sensory perceptions. Tob Prev Cessat. 2020;6(April). doi:10.18332/tpc/118437

3. Brown JL, Clegg Smith K, Zhu M, Moran MB, Hoe C, Cohen JE. Menthol and flavor capsule cigarettes in the Philippines: A comparison of pack design. Tob Induc Dis. 2019;17(November). doi:10.18332/tid/112718

4. World Health Organization. Advisory note: banning menthol in tobacco products: WHO study Group on Tobacco Product Regulation (TobReg). Geneva, Switzerland: World Health Organization; 2016. https://apps.who.int/iris/bitstream/ handle/10665/205928/9789241510332_eng.pdf?sequence=1. Accessed May 13, 2020.

5. Zatoński M, Herbeć A, Zatoński W, et al. Characterising smokers of menthol and flavoured cigarettes, their attitudes towards tobacco regulation, and the anticipated impact of the Tobacco Products Directive on their smoking and quitting behaviours: The EUREST-PLUS ITC Europe Surveys. Tob Induc Dis. 2018;16(Suppl 2). doi:10.18332/tid/96294

6. Smiley SL. Sociodemographic correlates of intention to quit smoking for good among U.S. adult menthol and nonmenthol smokers: Evidence from the 2013-2014 National Adult Tobacco Survey. Tob Prev Cessat. 2018;4(May). doi:10.18332/tpc/90968

7. Herbeć A, Zatoński M, Zatoński WA, et al. Dependence, plans to quit, quitting self-efficacy and past cessation behaviours among menthol and other flavoured cigarette users in Europe: The EUREST-PLUS ITC Europe Surveys. Tob Induc Dis. 2018;16(2). doi:10.18332/tid/111356

8. European Union. Directive 2014/40/EU of the European Parliament and of the Council. Off J Eur Union. 2014;2014(April):1-38. https://ec.europa.eu/health/sites/health/files/tobacco/docs/dir_201440_en.pdf. Accessed May $13,2020$.

9. Erku DA, Tesfaye ET. Tobacco control and prevention efforts in Ethiopia pre- and post-ratification of WHO FCTC: Current challenges and future directions. Tob Induc Dis. 2019;17(February). doi:10.18332/tid/102286

10. Shelley DR, Kyriakos CN, McNeill A, et al. Challenges to implementing the WHO Framework Convention on Tobacco Control guidelines on tobacco cessation treatment: a qualitative analysis. Addiction. 2019;115(3):527-533. doi:10.1111/add.14863

11. World Health Organisation. WHO Framework Convention on Tobacco Control: Guidelines for Implementation Article 5.3, Article 8, Articles 9 and 10, Article 11, Article 12, Article 13, Article 14. Geneva, Switzerland: World Health Organization; 2013. https://apps.who.int/iris/bitstream/handle/10665/80510/9789241505185_eng.pdf?sequence=1. Accessed May 13, 2020 .

CONFLICTS OF INTEREST

The author has completed and submitted the ICMJE Form for Disclosure of Potential Conflicts of Interest and none was reported.

FUNDING

There was no source of funding for this research.

PROVENANCE AND PEER REVIEW

Commissioned; internally peer reviewed. 